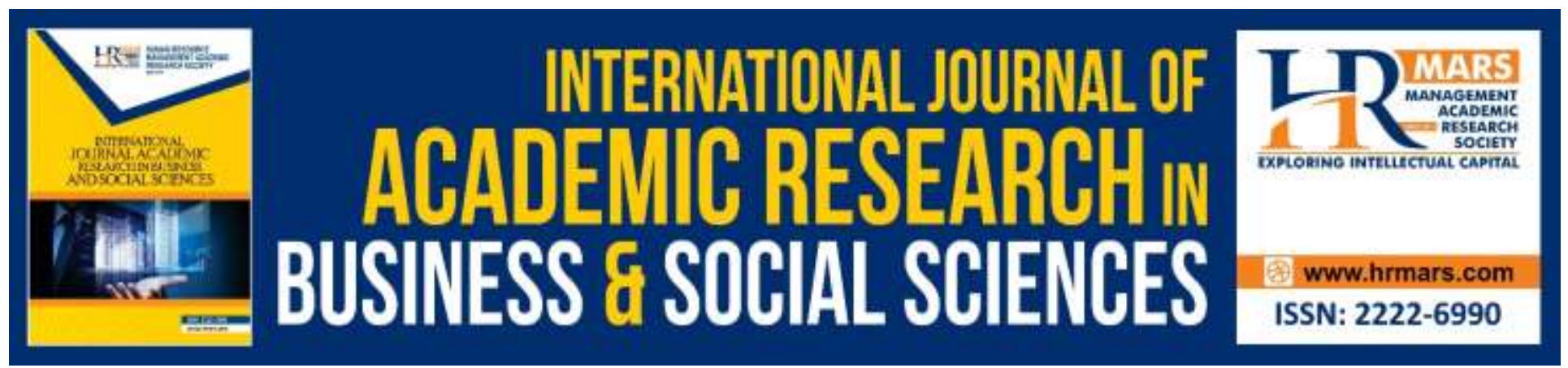

\title{
Factors for Success of Sunnah Movement in Perlis State
}

\section{Abdul Ghafur Abdul Hadi and Basri Ibrahim}

To Link this Article: http://dx.doi.org/10.6007/IJARBSS/v10-i4/7137

DOI:10.6007/IJARBSS/v10-i4/7137

Received: 18 February 2020, Revised: 04 March 2020, Accepted: 26 March 2020

Published Online: 10 April 2020

In-Text Citation: (Hadi \& Ibrahim, 2020)

To Cite this Article: Hadi, A. G. A., \& Ibrahim, B. (2020). Factors for Success of Sunnah Movement in Perlis State. International Journal of Academic Research in Business and Social Sciences, 10(4), 336-347.

Copyright: (c) 2020 The Author(s)

Published by Human Resource Management Academic Research Society (www.hrmars.com)

This article is published under the Creative Commons Attribution (CC BY 4.0) license. Anyone may reproduce, distribute, translate and create derivative works of this article (for both commercial and non-commercial purposes), subject to full attribution to the original publication and authors. The full terms of this license may be seen

at: http://creativecommons.org/licences/by/4.0/legalcode

\section{Vol. 10, No. 4, 2020, Pg. 336 - 347}

Full Terms \& Conditions of access and use can be found at http://hrmars.com/index.php/pages/detail/publication-ethics 


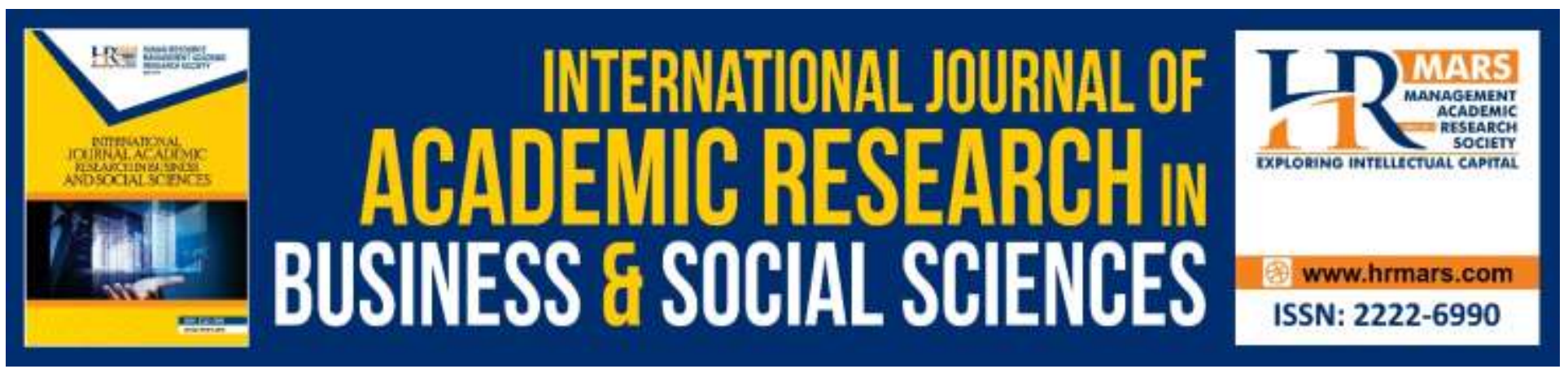

\title{
Factors for Success of Sunnah Movement in Perlis State
}

\author{
Abdul Ghafur Abdul Hadi ${ }^{1}$ and Basri Ibrahim² \\ ${ }^{1}$ Universiti Islam Malaysia, Cyberjaya, Malaysia, ${ }^{2}$ Universiti Islam Malaysia, Cyberjaya, Malaysia/ \\ Faculty of Islamic Contemporary Studies, Universiti Sultan Zainal Abidin, Terengganu, Malaysia. \\ Email: agahskoran@gmail.com.
}

\begin{abstract}
Sunnah Movement is synonym to Perlis state. Its emergence bringing a new stream of thought has begun influencing community's school of thought. New issues being posed begin to get attention as they suit with the revolving time. Definitely, history on development of this Sunnah Movement becomes an attraction for researcher to study. The objective of this article brought forward is to explain on the history of Sunnah Movement struggle in state of Perlis and the factors for success of the movement in Perlis in strengthening community's understanding of Sunnah practices. Methods of this study was of qualitative study. Data were collected from document analysis by referring to books especially those related to history either of foundation of Perlis state, of Sunnah Movement progress, classical fiqh books contemporary fiqh books, current fatwas, views of Sunnah Movement figures, questionnaires, observation and also interviews. Data collected were analysed and elaborated through inductive, deductive and comparative methods to obtain results complying with the assigned research objectives. This study found that Sunnnah Movement developed successfully in Perlis state upon five main factors which are support by the highest leader, enforcement of laws, credibility of Sunnah Movement leaders, foundation of institution for sunnah development and sunnah enhancement program to improve community's understanding of Sunnah practice. Sunnah Movement of Perlis gains support from the highest leader of the state which is the King himself and firm support from the highest administration of state which is the First Minister and Islamic administrative agency of state such as Religious and Malay Customs Council of Perlis (MAIPs), Mufti Department of Perlis and Religious Department of Perlis (JAIPs). Enforcement of Sunnah practice can be seen through JAIPs' practice by assignation of qualified imam through certification of teaching by Mufti Department of Perlis. Mufti Department also vigorously educates and nurtures community through education programs such as organisation of "Sunnah Village" event.
\end{abstract}

Keywords: Sunnah Movement, Mufti Department, Sunnah Village, Inductive, Deductive 
INTERNATIONAL JOURNAL OF ACADEMIC RESEARCH IN BUSINESS AND SOCIAL SCIENCES Vol. 10, No. 4, April, 2020, E-ISSN: 2222-6990 @ 2020 HRMARS

\section{Introduction}

Islam is the religion of truth. Its teachings bring guidance to all human beings to head towards success of the world and hereafter. However, humans' negligence has caused Islamic teachings to be forgotten little by little. Islamic civilisation built some time ago has fallen and become ruin of history. Some of the community begin to abstain from Islamic teachings and consequently perform wrongdoings of religion either in akidah or ibadah form. This does not happen only in Middle East but also in the Archipelago especially in Malaysia. On account of that, there appears the movement attempting to wake Muslim people up from their sleep to get back and appreciate Islamic teachings especially Sunnah of Rasulullah SAW seriously.

In Perlis state, there appears a reforming movement known as Sunnah Movement aiming to correct community and bring Muslim community back to the real teachings of Islam as those encouraged by Rasulullah S.A.W. This movement puts its efforts to fight heresy and superstitions striking the community especially community of Perlis state (Radzi \& Rahmat, 1996:9).

This article is posed to explain on the history of Sunnah Movement struggle in Perlis state and the factors for success of the movement in Perlis state in strengthening community's understanding on Sunnah practices and correcting wrongdoings in faith and ritual of the community. It is hoped that by reviewing the history of Sunnah Movement struggle and factors for success of Sunnah Movement being posed here, it can be a guide and example for Sunnah Movement in other places to succeed Sunnah Movement program in their respective places by considering the factors for success of Sunnah Movement in Perlis state as a guide. All these are forms of good contribution to reproduce a civilised Muslim community and triumph as in the time of Rasullullah S.A.W that Muslim community can live safely in the world and hereafter.

Writings on Sunnah Movement in Perlis state have been done a lot by writers especially the researchers of Perlis history. Among them are Nazim and Hazman (2018) discussing on the roles of Royal Institution of Perlis state and state religious agency such as Islamic and Malay Customs Council of Perlis (MAIPs), Mufti Department of Perlis, Islamic Department of Perlis (JAIPs) and Baitulmal of Perlis mobilising Sunnah of helping community and encouraging community to practise Sunnah. Mazli and Hamidah (2017), Nasir et al. (2009) and Mahmood (1996) meanwhile studied the history and phases of development of Sunnah Movement in Perlis. Ahmad (2016) elaborated on the roles of Sunnah Movement forming the state through local politics. Radzi and Rahmat (1996) performed a study on the relationship between Sunnah Movment in Perlis and other Sunnah Movement in Malaysia. Besides studies on Sunnah Movement, there are also studies on figures of Sunnah Movement mobilising Sunnah Movement in Perlis in which among them is the credibility and works of Sheikh Abu Bakar Al-Ashari studied by Nornajwa and Mustafa $(2015 ; 2008)$, Mohd Nasir (2006) and Zulkifli (1993). However, writings and researches above did not touch on the factors for success of Sunnah Movement specifically in correction of faith and ritual wrongdoings of community mainly Muslim community in Perlis.

\section{Research Methodology}

This writing was of qualitative research. Data were collected from document analysis by referring to books mainly on history either on history of Perlis state foundation, history of Sunnah Movemenet 
INTERNATIONAL JOURNAL OF ACADEMIC RESEARCH IN BUSINESS AND SOCIAL SCIENCES Vol. 10, No. 4, April, 2020, E-ISSN: 2222-6990 @ 2020 HRMARS

progress, classical figh books, contemporary fiqh books, current fatwas, and field studies and interviews of sunnah movement figures in which among them were Mohammad Yusof Amin (Mohamad Yusuf Libya) which is the Yang Dipertua of Perlis Islah Association and a Member of Fatwa Meeting Council of Perlis state, Abdul Hadi bin Osman which is a Member of Fatwa Meeting Council of Perlis state, Mat Ali bin Abdullah former Religious Inspector for Mata Ayer Perlis area, Sabri Lateh Imam of a mosque in Perlis and Othman Ismail former First Kadi of Perlis. Data collected were analysed and elaborated through inductive, deductive and comparative methods to gain appropriate results complying with the assigned research objectives.

\section{Findings}

Emergence of Sunnah Movement in Perlis state exactly coincided with its time. This movement appeared in early years of 1920s (Nasir et al., 2009:51). In the early emergence, this movement was unacceptable by the community as it was regarded as contradicting with Islamic teachings. Despite, resulting from efforts and practical examples implemented to understand the real sunnah doctrine as in the time of Rasullullah S.A.W, this movement began to be accepted wholeheartedly by Royal side. Therefore, little by little, community began to accept fikrah conveyed by Sunnah Movement. Among the most important contributions of Sunnah Movement was the suggestion for foundation of Alms and Fitrah Office of Perlis State by Haji Ahmad Hakim who was a figure of sunnah movement at that time. Then, introduction of Laws of Zakat and Fitrah Collection 1932 aiming to standardise alms collection and enable alms payment in the form of current money value and not fixing alms payment in the form of staple food as the community practice at that time (Nazim \& Hazman, 2018:270). Besides that, the objective of Sunnah Movement is to correct wrongdoings in rituals and faith of community. Idolatry practice of worshipping "Tok Keramat" in which among them were keramat Haji Mat Salleh in northern Perlis, keramat Tok Gua Lesung in Kangar and keramat Tok Seri Rama in Kaki Bukit that had become a practice of some groups from the community. In year 1950s, Muslim community together with Buddhist Chinese community held a feast and festival at the place. After the emergence of sunnah movement, process of faith cleansing from superstitions and heresy contamination was done by its figures in which among them were Syeikh Abu Bakar Al-Ashaari and friends. The result was that the belief and practice of idolatry slowly disappeared in year 1970s from Muslim community in Perlis State (Nornajwa \& Mustafa, 2015:81).

\section{History of Perlis State Establishment}

Perlis was a newly existing state in the history of states in Malaysia. Originally, Perlis was a district in the territory of Kedah kingdom. History of Perlis state began in the time of Sultan Muhyidin Mansur Shah (1653-1661) when Kota Sena was founded. Kota Sena today is known as Kangar. After that His Highness's Prince, Sultan Dhiauddin al-Mukarram Shah I (1661-1687) then formed Kota Indera Kayangan in the downstream of Perlis River. In the time of Sultan Dhiauddin al-Mukarram Shah II (1797-1803), His Highness was pronounced as Duli Raja Muda Perlis and Kedah in the agreements with British. His Highness was the one who match His Princess named Tengku Sofiah Sultan Dhiauddin Mukarram Shah II in year 1778 with an Arabic leader, Syed Harun Jamalullail (1825-1825). Through this marriage, Syed Harun Jamalullail was bestowed Arau territory as a marriage gift by Sultan of Kedah and became a chieftain there (Noor \& Hassan, 2018:12). 
INTERNATIONAL JOURNAL OF ACADEMIC RESEARCH IN BUSINESS AND SOCIAL SCIENCES Vol. 10, No. 4, April, 2020, E-ISSN: 2222-6990 @ 2020 HRMARS

In year 1825, after Syed Harun Jamalullail deceased, the Prince from the marriage with Wan Fatimah binti Dato' Johan Lela Perkasa, Syed Hussein Jamalullail (1805-1873) was assigned as the second Chieftain of Arau, but due to loss of Kedah to Siamese attack in year 1821-1838, Kedah was divided into four territories which were Kedah (Saiburi), Perlis (Polit), Kubang Pasu (Kubang Pasu) and Setul (Satun). Syed Hussein Jamalullail was assigned as Deputy Governor to Raja Long Krok as the Governor of Perlis at that time. Decease of Raja Long Krok in 1839 allowed Syed Hussein Jamalullail to take over the position of Perlis Governor. Raja Rama III who ruled Siam at that time awarded him with the title Phya Songkram Ramu Wichit Wilis Asmara Phya Polit (Phya Polit) upon Syed Hussin Jamalullail. The award had recognised Syed Hussin Jamalullail as 'Phya Polit' or King of Perlis beginning from 20 Mei 1843. Since then, Perlis stood alone as a state and his descendants rule until now. After Bangkok Treaty 1909 between kingdom of Siam and British, Perlis state unofficially was put under ruling of British (Azwan, 2016:6). Only in year 1930 after the treaty with British was sealed then Perlis became the last Malay state put under ruling of British Government officially and finally became a part of Federation of Malaya in year 1948.

\section{Progress of Sunnah Movement in Perlis State}

Community of Perlis were not alienated from the change brought by reforming group. This reforming group was known as Sunnah Movement. Among the main reasons of this group's emergence in Perlis state was to improve the life of Perlis community itself. There were many religious wrongdoings that had become customs in the community. Citizens of Perlis state at that time were highly-influenced by practices of Siamese customs who were known of its Buddhism religion. This situation happened due to the position of Perlis state which was under the governance of Siamese kingdom. Indirectly, influence of Siamese community practices were also practised in Malay community (Nornajwa dan Mustaffa 2015:8). Community at that time also practised many superstitious doings violating the faith (Nasir, 2006).

History of settlement for citizens of Perlis state began since prehistoric era based on finding of ancient relic found in Gua Tegun Lembu (Tengku Lembu) in Beseri, Perlis (Perlis State Goverment, 2001:8). After that, the life of community was shadowed by ideological and religious influence molding the life of community according to its phases of influence. Beginning from phase of pre Hindu-Buddha, phase of Hindu-Buddha, then phase of Islam beginning in the twelfth century starting to take place and determine the community's lifestyle and phase of colonialisme (Mugiyono, 2016:24).

Islamic influence inherited by the community from generation to generation in community of Perlis state were in some of them had jumbled with influence of traditional practices of Hindu-Buddha teachings by attachment of several Quranic verses or being sounded imitating Quranic verses. Some had shape like Quranic calligraphy. This situation caused the community to become confused and practise them. Some practices meanwhile were contradicting with Islamic teachings but due to lack of exposure and knowledge, community kept on practicing them without realising that the practices were violating the religion. Among the practices performed by the community violating the religion's teachings was the practice of "melenggang perut" (belly rolling). Practice of "melenggang perut" is a practice of splitting the coconut on the pregnant mother's belly, then the candle is lit to detect the 
INTERNATIONAL JOURNAL OF ACADEMIC RESEARCH IN BUSINESS AND SOCIAL SCIENCES Vol. 10, No. 4, April, 2020, E-ISSN: 2222-6990 @ 2020 HRMARS

gender of the fetus either of male or female. Ritual of eating pulut kuning (yellow glutinous rice) being resembled with clothes of 'monks' was also held during the ritual. Ritual of cradle swing is a ritual held and performed to the newborn baby. During the swing, various poems and ronggeng singings were uttered specifically to celebrate the birth of the baby (Nornajwa \& Mustaffa, 2015:9)

In early decades of 1900 in Perlis, emerged Sunnah Movement correcting religious wrongdoings of the community either of faith or ritual. Several figures such as Lebai Kechik from Indonesia and Syed Ibrahim from Hadramaut had begun to propagate Sunnah stream in Perlis. After that, appeared a figure named Haji Ahmad Muhammad or known as Haji Ahmad Hakim, a Great Judge of Perlis in 1920s who pioneered the reformation with Wan Ahmad Wan Daud and Sheikh Ahmad bin Mohd Hashim. Besides these 'Three Ahmads', then appeared Abdul Wahab Abdullah and Sheikh Abu Bakar al-Ashaari brought to Perlis in middle 1930s to strengthen this Sunnah Movement (Fadli, 2019). This movement was to bring revolution to Muslim community in Perlis. Objective of Perlis Sunnah Movement was to cleanse the faith of Muslim people from association with Allah, call Muslim peopleto practise Sunnah and abandon heresy and abolish superstitious practices that had been nurtured in life of some Muslim community (Nornajwa \& Mustaffa, 2015:8).

At intermediate phase, progress of Sunnah Movement (1946-1970) figures such as Haji Abdul Ghani Dato Sakti, Ustazah Shaharom Bee, Haji Mokhtar Ismail, Fakih Sidin, Abu Bakar Taib, Syeikh Noor, Ustaz Abdul Rahman, Haji Alwi, Syeikh Ahmad and Syeikh Abu Bakar Al-Ashaari mold the Sunnah Movement. In this phase, the spread of Sunnah Movement doctrine was not just through teachings in the mosque and surau but also through writings of booklets and books causing the method of Sunnah Movement to spread throughout the whole state.

In Perlis, Sunnah Movement develops positively without arising big conflict. Interestingly, Sunnah Movement in Perlis state develops vigorously and harmoniously and alongside with political progress. Religious figures in Perlis, mainly supporter of Sunnah Movement had chosen to be with UMNO. Figures like Sheikh Ahmad Mohd Hashim, Wan Ahmad Wan Daud, Salleh Othman, Sheikh Abu Bakar al-Ashaari, Abu Bakar Hamzah, Ustaz Ahmad Long, and others had become figures of UMNO. Indeed, after General Election of Perlis State on 20 Mei 1959, Sheikh Ahmad Mohd Hashim was assigned as First Minister of Perlis, while Ustaz Salleh Othman was assigned by UMNO as Chairman of Malayan Religious Division in 1949. Ustaz Abu Bakar Hamzah became Chief of UMNO Men in Perlis in 1953-1955. One of the main factors that they were with UMNO was that Sheikh Ahmad and Wan Ahmad Wan Daud, who were regarded as the main figures of Sunnah Movement in Perlis, had become leader of UMNO (Fadli, 2019).

Besides that, Royal side had accepted the ideology of Sunnah Movement positively. Most of Sunnah Movement leader had been given trust by the King to administer Islamic Council of Perlis functioning as the advisor of King in religious and Malay customs affairs and regulator of Islamic activities in the state. Besides Islamic Council of State, positions in Syaria committee responsible of producing fatwa were also occupied by figures of Sunnah Movement. Through the power assigned, Sunnah Movement continued its effort to correct community's practices and rituals violating the teachings of religion. To enlighten the delivery of doctrine and ideology of this Sunnah Movement, 
INTERNATIONAL JOURNAL OF ACADEMIC RESEARCH IN BUSINESS AND SOCIAL SCIENCES Vol. 10, No. 4, April, 2020, E-ISSN: 2222-6990 @ 2020 HRMARS

imams of the mosque were assigned from among the supporters and those who were in doctrine alongside with Sunnah Movement.

Ideology and doctrine of Sunnah Movement did not only spread through political influence and administration, ideology and doctrine of this Sunnah Movement were also spread through mass media. At that time, there were magazines and newspapers specifically established to spread idea of this Sunnah Movement like Saudara, Pengasuh, 'al-Urwat al-Wuthqa', al-Ikhwan, majalah al-Imam and al-Manar which had become the main contributor of Sunnah Movement spread in Perlis (Mazli \& Hamidah, 2017:3).

\section{Factors for Success of Sunnah Movement}

There are five factors recognised as contributor towards success of Sunnah Movement in Perlis. The factors are first, support from the ruler and the highest administrator of Perlis towards Sunnah Movement and they even helped to establish Sunnah Movement in the state. Second, enforcement of laws by ensuring that Sunnah Movement school of thought can be propagated to the community. Third, factor of credibility in Sunnah Movement figures. Fourth, religious institution played its role in spreading doctrine of Sunnah and fifth organisation of Sunnah Enhancement programs.

\section{Support from the Ruler and State Administatives}

King is the pillar for ruling of state. Beginning from ruling era of Raja Syed Alwi Jamalullail, Sunnah Movement had already got attention of Royal side and became example for the later Kings. For example, by amending Syariah Court (Amendment) Enactment 1930 in the ruling era of Raja Syed Alwi Jamalullail, administration of Islamic legislation in Perlis became systematic. Through amendment of this act, process of teaching and delivering religious knowledge in Perlis must be accompanied with credential and only books approved by Raja Syed Alwi Jamalullail can be taught in Perlis (Mohd Nazim and Hazman, 2018:263). Besides that, the Palace can also utilised as teaching area. DYMM Female King of Perlis Tuanku Budriah had organised religious studies class in Palace of Arau and around Kangar guided by Dato' Setia Bakti Ustaz Ahmad Nordin who was a figure of Perlis Sunnah Movement at that time (Nazim \& Hazman,2018:58). As the leader of religion, Tuanku Syed Putra Jamalullail as King of Perlis at that time frequently attend to the mosques throughout Perlis. Besides for prayer, His Highness also delivered His words calling the community towards practice of Sunnah and strengthening of solidarity. This practice of His Highness indirectly boosted up Sunnah Movement throughout Perlis. This legacy is continued by His Highness apprentice, Tuanku Syed Sirajuddin Jamalullail as the King of Perlis at the meantime.

First Ministers of Perlis were mostly of figures from Sunnah Movement. Through support of the King and First Minister, several highest positions in state religious institution such as Religious and Malay Customs Council of Perlis (MAIPs), State Islamic Department of Perlis (JAIPs) and Mufti Department of Perlis were occupied by those from supporters of Sunnah Movement. This eased the activity of propagating the Sunnah Movement doctrine in the state. Officials of mosque were also assigned from among the supporters of Sunnah Movement. Sunnah Movement in Perlis had a strong workforce to ensure that it can be propagated. For example, Tuan Haji Ahmad Hakim was the first Yang Dipertua of MAIPs. 
INTERNATIONAL JOURNAL OF ACADEMIC RESEARCH IN BUSINESS AND SOCIAL SCIENCES Vol. 10, No. 4, April, 2020, E-ISSN: 2222-6990 @ 2020 HRMARS

\section{Enforcement of Laws}

Enforcement of laws is a factor succeeding Sunnah Movement in Perlis. Through laws, Sunnah Movement can develop. Realising this fact, earlier figures of Sunnah Movement had put their efforts of soldering the main doctrine of Sunnah Movement in the state law. Resulting from continuous efforts, this Sunnah Movement has posed a big impact especially in the formation of Undang-Undang Tubuh Negeri Perlis 1948. In article 5(1) it is stated that "Religion for Perlis state is Islam of Ahli Sunnah Waljamaah which is not bound to any sect" even the term Ahli Sunnah Wa al-Jamaah is emphasised seven times in Constitution of Perlis State (Nazim \& Hazman, 2018:64). Allocation also states that qualifying conditions of descendants of DYMM Tuanku Syed Putra Jamalullail to be crowned as the succeeding king, the king, the acting king and inheritor of Perlis kingdom is that they must be Muslim with Ahli Sunnah Waljamaah belief. Indeed, this Ahli Sunnah method is widened more by making it as a qualifying condition for a First Minister and Secretary of Perlis Government to be assigned by King of Perlis. This situation provides a strong basis for Sunnah Movement to spread in Perlis.

Based on this strong basis, many acts and enactments of state were amended after that according to Ahli Sunnah Wa al-Jamaah method as brought by sunnah movement. For example, Section 119 Misconduct of Teaching Islam or Matters on Islam without Credential Enactment of Islamic Administration 2006 conditions that any person who wants to teach religion in Perlis must get credential. Regulation to issuing of credential can be performed by only issuing credential to person who aligns with Sunnah Movement school of thought. This practice actually can strengthen Sunnah Movement as only teaching based on Sunnah Movement doctrine is spread in Perlis.

Besides that, through enforcement of laws, it can regulate and avoid community from involving with wrong teaching and obtaining from wrong reference. For example in year 1956, acting as Yang Dipertua of MAIPs, Tuan Haji Ahmad Hakim had banned the book The Great Man of The East as the contents of the book included many elements of insult towards the purity of Islam (Nazim \& Hazman, 2018:359.

\section{Credibility of Sunnah Movement Leaders}

This Sunnah Movement in Perlis is mostly spread by figure of Sunnah Movement since the beginning of sunnah movement until now. Persistent and continuous efforts by these sunnah movement figures had succeeded in raising awareness among community to return to the real Islamic teachings as in the time of Prophet Muhammad S.A.W previously.

Credibility of Tuan Haji Ahmad Hakim, as an example that in the beginning suggested a systematic zakat collection system in Perlis state by taking example from zakat practice during the time of Prophet Muhammad S.A.W, had gained attention from the King and community. Before this, zakat collection was only in staple food form like rice either distributed personally to asnaf or through religious teacher, 'Tok Lebai' or 'Tok Haji' (Nazim \& Hazman, 2018:264). This group became the religious reference for the local community at that time. Finally, Law of Zakat and Fitrah Collection Perlis 1932 was endorsed. Collection of zakat was not only in staple food form but even in monetary form. Good relationship between Tuan Haji Ahmad Hakim and King of Perlis at that time had 
INTERNATIONAL JOURNAL OF ACADEMIC RESEARCH IN BUSINESS AND SOCIAL SCIENCES Vol. 10, No. 4, April, 2020, E-ISSN: 2222-6990 @ 2020 HRMARS

facilitated the progress of Sunnah Movement a lot. Besides that, the community admired and was attracted to his method of propagating Sunnah Movement doctrine.

At the same time, Haji Ahmad Hakim had invited Syeikh Abu Bakar Al-Ashaari to help him in rainsing awareness among the community on practice of Sunnah. Syeikh Abu Bakar Al-Ashaari became imam and religious teacher and helped to educate community to get back practising the real Sunnah through Friday sermon, writings of book and magazine and religious class conducted by him. At that time, combination of Haji Ahmad Hakim, Syeikh Ahmad bin Mohd Hashim and Wan Ahman bin Wan Daud became the main spokesman of Sunnah Movement while Syeikh Abu Bakar Al-Ashaari prepared teaching materials, fatwa and commentaries spreading this school of thought (Nornajwa \& Mustaffa, 2015:59-60). Effort of spreading this sunnah movement was bolstered by Sheikh Noor who found Islah association in year 1965. Community got exposure and knowledge on Sunnah through classes organised by this Islah association. Now, efforts of strengthening Sunnah Movement is resumed by Mohd Asri Zainul Abidin as Mufti of Perlis state.

Credibility of politicians, among them were the First Ministers of Perlis from among them who were aligned with Sunnah Movement. This condition had smoothened further the process of propagating Sunnah Movement as they got full support from among the highest leaders of state to conduct activity. Among the First Minister renowned of Sunnah Movement was Syeikh Ahmad bin Mohd Hashim and Shahidan bin Kasim.

\section{Foundation of Sunnah Development Institution}

A movement would not develop without executive support executing implementing the ideology of the movement. That is also true to this Sunnah Movement. In its early emergence, Alawiyah school and Female Religious School became the earliest Institution to spread this sunnah movement (Radzi dan Rahmat, 1996 :107). Madrasah Alawiyah at that time followed learning system of Egypt. Learning only involved muzakirah (notes) and there were those who had advanced lesson from Naylul Autar book. Graduates from this madrasah were sent to further studies overseas or to Kolej Islam Malaya (Nazim \& Hazman, 2018:273). Then they returned to the country and enhanced this Sunnah Movement. Among the famous figure of Alawiyah was Ustaz Ahmad Nordin.

During the ruling era of DYMM Tuanku Syed Putra Jamalullail, state Islamic agency was standardised according to demand of ahli Sunnah Wa al-Jamaah. To succeed in in this agency, state religious administration was restructured that it would become stronger. JAIPs was separated from MAIPs in year 1989 then separated from Mufti Office in year 1996. In education sector, it was endorsed of the foundation of Islamic Foundation of Perlis in year 1987 responsible in foundation of Islamic primary school and dan secondary school of Madrasah Alawiyah Ad-Diniyyah Arau. In year 1998 an Islamic Higher Institution of Perlis (IPTIPs) was founded under Islamic Foundation of Perlis

(Nazim \& Hazman, 2018:66). In year 2017, Center of Sunnah was founded, this centre conducted Turath book lesson class. In year 2018, afternoon religious school was introduced to expose children on the clear understanding of Ahli Sunnah Wa al-Jamaah. 
INTERNATIONAL JOURNAL OF ACADEMIC RESEARCH IN BUSINESS AND SOCIAL SCIENCES Vol. 10, No. 4, April, 2020, E-ISSN: 2222-6990 @ 2020 HRMARS

\section{Sunnah Enhancement Program}

Sunnah enhancement program is the main core of this movement. Through the enhancement program organised by community, understanding and explanation on Sunnah Movement was performed seriously. Besides that, other programs were also arranged aiming to correct wrongdoings of faith and ritual in the community and provide examples of the real Sunnah practices to be implemented. In the emergence of Sunnah Movement, teaching program in mosque, surau and Friday sermon were the main channel of executing this Sunnah Movement program. Book translated by Sheikh Abu Bakar Al-Ashaari which was kitab Jawahir al-Bukhari wa Syarh al-Qistalani was among the hadith book taught and introduced to the community. In tafsir field, the work Essence of Tafsir for Juzuk 'Amma was introduced as a part of the main reading (Nornajwa \& Mustafa,2015:60).

The Palace was also not left behind playing its important role in the effort of propagating this Sunnah Movement doctrine. For example, religious classes were organised in the Palace (Nazim \& Hazman, 2018:58). Presence of the King performing prayer in the state mosques provided good example for the community. Presence of the King performing the rituals together with the community had awakened learning and inquiry spirit among the community and planned programs and activities had succeded in educating the community according to Sunnah method introduced.

Besides local figures, several foreign figures were invited to deliver speech in the state in which among them were Nouman Ali Khan, Zakir Naik, Dr. Bilal Philips and Sheikh Dr Abdul Muhsin Mohammad al-Qasim. Besides that, to spark up community's understanding on sunnah, program series of "Sunnah Village" were held. This program was an example of knowledge event to introduce Muslim lifestyle according to Sunnah to the community (Nazim \& Hazman, 2018:243-249).

\section{Conclusion}

Sunnah Movement in Perlis is a movement emerging to correct wrongdoings of faith and ritual of Muslim people in Perlis state. The struggle of Sunnah Movement aims to raise awareness among the community on the wrongdoings that they do and then correct them and guide them to return to uphold sunnah as practised during the time of Rasulullah S.A.W.

Efforts done by this Sunnah Movement achieved success based on five main factors. First, good relationship between figures of Sunnah Movement with the state rulers especially the King of Perlis became the main factor in the success of Sunnah Movement. Resulting from this good relationship, several important positions in state religious agency were given to supporters of Sunnah Movement. Second, enforcement of laws. Effort of building a strong basis by assigning the term of Ahli Sunnah Waljamaah in Undang-Undang Tubuh Negeri Perlis had guaranteed the strength of Sunnah Movement doctrine. The gazette of Undang-Undang Kecil after that must align with state Islamic belief basis of the state that held to Ahli Sunnah Waljamaah belief. Enforcement and regulation to other teachings besides Ahli Sunnah Waljamaah could be impeded. This ensured that this sunnah movement stream could be spread.

Third, credibility factor in figures of Sunnah Movement. The credibility of Sunnah Movement leaders had become a catalyst of Sunnah Movement propagation in Perlis. In its early emergence, 
INTERNATIONAL JOURNAL OF ACADEMIC RESEARCH IN BUSINESS AND SOCIAL SCIENCES Vol. 10, No. 4, April, 2020, E-ISSN: 2222-6990 @ 2020 HRMARS

names of figures such as 'Three Mat' and Sheikh Abu Bakar Al-Ashaari had become the main mover of Sunnah Movement in early phase. This credibility was resumed by Sheikh Noor who founded Perlis Islah Association, Ustaz Nordin and Ustaz Rahman. Involvement of Sunnah Movement figures in politics of ruler had opened the space for spread of Sunnah Movement through politics. Shahidan bin Kassim is among the political figure renowned of Sunnah Movement. Recently, Mufti of Perlis Dr. Mohd Asri Zainul Abidin has brought a major impact in Sunnah Movement. Fourth, institution propagating Sunnah doctrine. Establishment of several learning institutions beginning from primary school until level of higher learning institution in Perlis implementing Sunnah studies has facilitated in the strengthening of Sunnah to every generation of community.

Fifth, integrated Sunnah Enhancement Programs organised involving all parties beginning from the King as the state ruler, state Islamic administration through state religious agency and figures of Sunnah Movement, have ensured that Sunnah Movement thought is widely spread to be understood and practised by the community to achieve well-being in the world and hereafter.

\section{Corresponding Author}

Abdul Ghafur bin Abdul Hadi, Universiti Islam Malaysia, Cyberjaya, Malaysia.

Email:agahskoran@gmail.com.

\section{Acknowledgement}

Special thanks to the Majlis Agama Islam Dan Adat Istiadat Melayu Perlis for funding the research under Jamalullail Professorial Chair, Universiti Islam Malaysia.

\section{References}

Abdul, H. O. (2019) Sejarah dan faktor kejayaan Gerakan Sunnah di Perlis. [interview].

Azwan, A. (2016), Transformasi Dinamika Politik Elit di Perlis, Kurun ke 19 sehingga 1970-An, Tesis Phd, Universiti Sains Malaysia.

Kerajaan Negeri Perlis. (2001), Syed Sirajuddin Putra Jamalullail, Alor Setar, Perbadanan Percetakan Nasional Malaysia Berhad.

Maszli, M., \& Hamidah, M. (2017), The Historical Development of the "sunnah" Reform Ideology in the state of Perlis, Malaysia, SAGE Open, July-September.

Mat, A. A. Former Inspector Agama of Mata Air area under JAIPs. (2019). Sejarah dan faktor kejayaan Gerakan Sunnah di Perlis. [interview].

Mogiyono. (2016), Intergrasi Islam dan Peradaban Melayu: Studi Eksploratif historis terhadap perkembangan Peradaban Melayu Islam di Nusantara, Jurnal IImu Agama, Vol 17, No 1.

Mohammad, Y. A., Member of Perlis Fatwa Committee \& YDP of al-Islah Perlis Association. (2019) Sejarah dan faktor kejayaan Gerakan Sunnah di Perlis. [interview].

Mohd, F. G. (2019), Pertubuhan PAS Perlis: Kebangkitan Islam di Utara, www.harakahdaily.net, keluaran 3 Julai 2019.

Mohd, N. A. H. (2009), The Role of The Islah Movement in The State's Contitution of Perlis, Malaysia,Journal of Politics and Law, Vol. 2, No 2. 
INTERNATIONAL JOURNAL OF ACADEMIC RESEARCH IN BUSINESS AND SOCIAL SCIENCES

Vol. 10, No. 4, April, 2020, E-ISSN: 2222-6990 @ 2020 HRMARS

Mohd, N. M. N., \& Hazman, H. (2018), Sirajul Muluk Majlis Agama Islam dan Adat Istiadat Melayu Perlis (MAIPs) di bawah naungan tiga putera Jamalullail, Kuala Lumpur, Dewan Bahasa Dan Pustaka.

Khairuldin, W. M. K. F. B. W., Embong, A. H., Hassan, S. A., Yasin, M. F. M., \& Anas, W. N. I. W. N. (2019). Strategic management in fatwa-making process. Academy of Strategic Management Journal, 18(4), 1-6.

Mohd, R. O., and Rahmat, O. K. (1996), Gerakan Pembaharuan Islam Satu Kajian di negeri Perlis dan Hubung kaitnya Dengan Malaysia, Pulau Pinang, Universiti Sains Malaysia.

Nurnajwa \& Mustafa, A. (2015), Biografi Ulama Malaysia Syeikh Abu Bakar Al-Ashaari Mufassir Islah Penerus zaman, Kuala Lumpur, Dewan Bahasa dan Pustaka.

Othman, I., Former Chief Kadi of Perlis. (2019, Jun 20) Sejarah dan faktor kejayaan Gerakan Sunnah di Perlis [interview].

Sabri, L. Imam of Mosque in Perlis. (2019, Jun 4) Sejarah dan faktor kejayaan Gerakan Sunnah di Perlis [interview].

Khairuldin, W. M. K. F. W., Anas, W. N. W. I. N., Embong, A. H., Hassan, S. A., Hanapi, M. S., \& Ismail, D. (2019). Ethics of mufti in the declaration of fatwa according to islam. Journal of Legal, Ethical and Regulatory Issues, 22(5), 1-6.

Shukor, M. (2006), Bagaimana Berkembangnya Fahaman Sunnah Hingga Ke Perlis, Warisan Indera Kayangan, Perbadanan Perpustakaan Awam Perlis.

YM, C. P. T. P. (1995), Putra, Selangor, Time Editions Pte Ltd. 